ISSN 1678-3921

Journal homepage: www.embrapa.br/pab

For manuscript submission and journal contents, access: www.scielo.br/pab

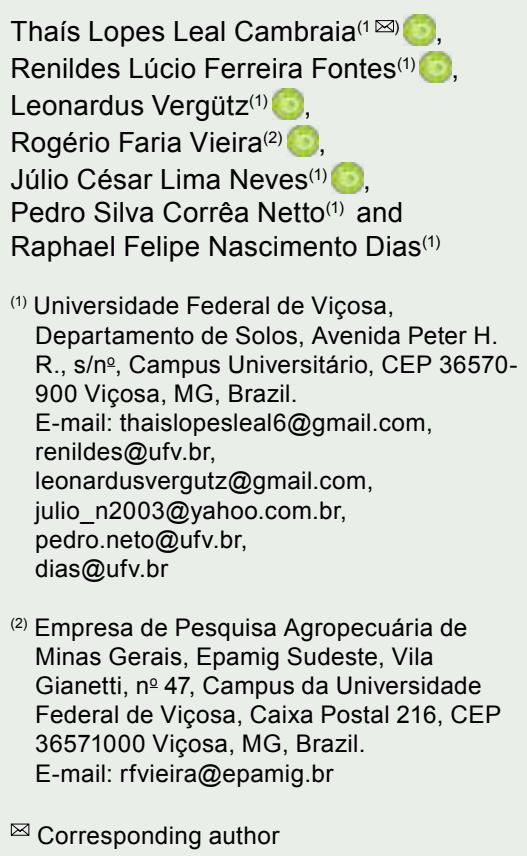

Accepted

May 13, 2019

How to cite

CAMBRAIA, T.L.L.; FONTES, R.L.F.; VERGÜTZ, L.; VIEIRA, R.F.; NEVES, J.C.L.; CORREAA NETTO, P.S.; DIAS, R.F.N. Agronomic biofortification of common bean grain with zinc. Pesquisa Agropecuária Brasileira, v.54, e01003, 2019. DOI: https://doi. org/10.1590/S1678-3921.pab2019.v54.01003.

\section{Agronomic biofortification of common bean grain with zinc}

\begin{abstract}
The objective of this work was to evaluate the effects of the split and combinated application of foliar zinc $(\mathrm{ZnF})+$ soil $\mathrm{Zn}(\mathrm{ZnS})$ on $\mathrm{Zn}$ concentration in the grains ( $\mathrm{ZnCG}$ ) of common bean (Phaseolus vulgaris). Two experiments were carried out in a greenhouse during two seasons. In the first experiment, two common bean cultivars received six $\mathrm{ZnF}$ rates $(0$, $120,240,480,720$, or $1,200 \mathrm{~g} \mathrm{ha}^{-1}$ ), with split applications at the R5, R7, and $\mathrm{R} 8$, or R7 and R8, or R8 plant stages. In the second experiment, one cultivar received three $\mathrm{ZnS}$ rates $\left(0,5\right.$, or $\left.10 \mathrm{~kg} \mathrm{ha}^{-1}\right)$ combined with $\mathrm{ZnF}$ rates $(0$, $1,1.5,3,6$, or $\left.10 \mathrm{~kg} \mathrm{ha}^{-1}\right)$. In the first experiment, with the $\mathrm{ZnF}$ increment, ZnCG increased linearly from 15.3 to $20.7 \mathrm{mg} \mathrm{kg}^{-1}$. ZnF splitting did not affect $\mathrm{ZnCG}$. In the second experiment, $\mathrm{ZnF}$ without $\mathrm{ZnS}$ did not affect $\mathrm{ZnCG}$. ZnS doubled $\mathrm{ZnCG}$ in comparison with the treatment without $\mathrm{ZnS}$ application. At $5 \mathrm{~kg} \mathrm{ha}^{-1} \mathrm{ZnS}$, the highest $\mathrm{ZnCG}\left(67.5 \mathrm{mg} \mathrm{kg}^{-1}\right)$ was obtained with 7.8 $\mathrm{kg} \mathrm{ha}^{-1} \mathrm{ZnF}$. At $10 \mathrm{~kg} \mathrm{ha}^{-1}$, the highest $\mathrm{ZnCG}\left(66 \mathrm{mg} \mathrm{kg}^{-1}\right)$ was obtained with $4.9 \mathrm{~kg} \mathrm{ha}^{-1} \mathrm{ZnF}$. ZnF splitting is not advantageous over a single application, and the combination of $\mathrm{ZnF}$ and $\mathrm{ZnS}$ increases $\mathrm{ZnCG}$ in common bean, in greenhouse conditions.
\end{abstract}

Index terms: Phaseolus vulgaris, concentration of $\mathrm{Zn}$ in grains, food quality, zinc fertilization.

\section{Biofortificação agronômica de grãos de feijão com zinco}

Resumo - O objetivo deste trabalho foi avaliar os efeitos da aplicação parcelada e combinada de zinco foliar $(\mathrm{ZnF})+\mathrm{Zn}$ no solo $(\mathrm{ZnS})$ sobre o teor de $\mathrm{Zn}$ dos grãos (TZnG) do feijão-comum (Phaseolus vulgaris). Dois experimentos foram realizados em casa de vegetação durante dois períodos. No primeiro experimento, duas cultivares de feijão-comum receberam seis doses de $\mathrm{ZnF}\left(0,120,240,480,720\right.$, ou $\left.1.200 \mathrm{~g} \mathrm{ha}^{-1}\right)$, com aplicações parceladas nos estágios da planta R5, R7 e R8, ou R7 e R8, ou R8. No segundo experimento, uma cultivar recebeu três doses de $\mathrm{ZnS}\left(0,5\right.$ ou $\left.10 \mathrm{~kg} \mathrm{ha}^{-1}\right)$ combinadas com doses de $\mathrm{ZnF}\left(0,1,1,5,3,6\right.$ ou $\left.10 \mathrm{~kg} \mathrm{ha}^{-1}\right)$. No primeiro experimento, com o incremento do $\mathrm{ZnF}$, o TZnG aumentou linearmente de 15,3 para $20,7 \mathrm{mg} \mathrm{kg}^{-1}$. O parcelamento do $\mathrm{ZnF}$ não afetou o $\mathrm{TZnG}$. No segundo experimento, o $\mathrm{ZnF}$ sem o $\mathrm{ZnS}$ não afetou o TZnG. O ZnS dobrou o TZnG em comparação ao tratamento sem aplicação de $\mathrm{ZnS}$. Com $5 \mathrm{~kg} \mathrm{ha}^{-1}$ de $\mathrm{ZnS}$, o mais alto TZnG (67,5 mg kg-1) foi obtido com 7,8 $\mathrm{kg} \mathrm{ha}^{-1} \mathrm{de} \mathrm{ZnF}$. Com $10 \mathrm{~kg} \mathrm{ha}^{-1}$, o mais alto TZnG $\left(66,0 \mathrm{mg} \mathrm{kg}^{-1}\right)$ foi obtido com $4,9 \mathrm{~kg} \mathrm{ha}^{-1} \mathrm{de}$ $\mathrm{ZnF}$. O parcelamento do $\mathrm{ZnF}$ não é vantajoso em relação à aplicação única, e a combinação ZnF e ZnS aumenta o TZnG do feijão-comum em casa de vegetação.

Termos para indexação: Phaseolus vulgaris, teor de Zn nos grãos, qualidade alimentar, adubação com $\mathrm{Zn}$. 


\section{Introduction}

Biofortification is a mean to increase the $\mathrm{Zn}$ content (and other minerals and vitamins) in the edible parts of crop plants. Agronomic biofortification with $\mathrm{Zn}$ fertilization of crop plants is a rapid solution to enrich food with this micronutrient. Biofortification techniques aim at increasing $\mathrm{Zn}$ concentration in edible plant parts, besides increasing the proportion of bioavailable $\mathrm{Zn}$. On average, the $\mathrm{Zn}$ bioavailability is $25 \%$ of the $\mathrm{Zn}$ ingested (Clemens, 2014).

Common bean (Phaseolus vulgaris L.) is the most cultivated grain legume in the world, and it is the main staple food for lower-income populations of many countries in America and Africa (Blair, 2013). The average $\mathrm{Zn}$ concentration in common bean grains is $35 \mathrm{mg} \mathrm{kg}^{-1}$, which is among the highest ones for crop plants (Beebe et al., 2000). Therefore, common bean grains has been a target for biofortification, aiming at increasing the $\mathrm{Zn}$ concentration to $56 \mathrm{mg} \mathrm{kg} \mathrm{kg}^{-1}$ (White \& Broadley, 2011). Although common bean is considered a crop with low-Zn use efficiency (Moreira et al., 2018), grain- $\mathrm{Zn}$ concentration over $56 \mathrm{mg} \mathrm{kg}{ }^{-1}$ was obtained only with foliar $\mathrm{Zn}$ application in Brazil (Ram et al., 2016).

Biofortification studies worldwide concentrate, in general, on cereals as rice and wheat. $\mathrm{Zn}$ foliar $(\mathrm{ZnF})$ application has increased the $\mathrm{Zn}$ concentration in grains ( $\mathrm{ZnCG})$ of cereals, especially wheat, whereas $\mathrm{Zn}$ applied to soil $(\mathrm{ZnS})$ at sowing generally had little effect on ZnCG of cereals under field conditions. The combination of $\mathrm{ZnF}$ and $\mathrm{ZnS}$ has provided small increase of $\mathrm{ZnCG}$ in cereals, in comparison to $\mathrm{ZnF}$ alone (Cakmak \& Kutman, 2018).

Few studies have evaluated the effect of the combined $\mathrm{ZnS}$ and $\mathrm{ZnF}$ on $\mathrm{ZnCG}$ of grain legumes. In raw grains of pea, $\mathrm{ZnS}\left(0,4\right.$, or $8 \mathrm{mg} \mathrm{ZnSO}_{4} 7 \mathrm{H}_{2} \mathrm{O}$ $\mathrm{kg}^{-1}$ soil) increased $\mathrm{ZnCG}$ from 34 to $70 \mathrm{mg} \mathrm{kg}$, but $\mathrm{ZnF}$ alone increased more efficiently the $\mathrm{ZnCG}$ (Poblaciones \& Rengel, 2016). Thus, results with $\mathrm{ZnS}$ in pea are more encouraging than those for cereals aiming to increase ZnCG. A study conducted with common bean in five sites in São Paulo state, Brazil, indicates that $\mathrm{ZnF}$ increases $\mathrm{ZnCG}$ between 4 and 30\% (Ram et al., 2016). However, the effects of $\mathrm{ZnS}+\mathrm{ZnF}$ on $\mathrm{ZnCG}$ have not been studied in common bean.

Studies with wheat (Cakmak et al., 2010; Ajiboye et al., 2015) and rice (Boonchuay et al., 2013) were carried out to test $\mathrm{ZnF}$ at different stages of this crop development (or combinations of stages) with a fixed rate of $\mathrm{Zn}$ (4 to $5 \mathrm{~kg} \mathrm{ha}^{-1}$ of $\mathrm{ZnSO}_{4} \cdot 7 \mathrm{H}_{2} \mathrm{O}$ ). Results indicated that $\mathrm{ZnF}$ should be applied after flowering for rice, and during grain-filling for wheat. We did not find any study examining the effect of splitting $\mathrm{Zn}$ fertilizers applied on foliage into two or three applications, at different growth stages of common bean (or other crop) on ZnCG.

The objective of this work was to evaluate the effects of splitting $\mathrm{Zn}$ fertilizer into two or three applications on grain $\mathrm{Zn}$ concentration of common bean, and the effectiveness of the combined $\mathrm{Zn}$ fertilization (soil + foliar) on grain $\mathrm{Zn}$ concentration.

\section{Materials and Methods}

Two experiments were carried out in a greenhouse in the municipality of Viçosa $\left(20^{\circ} 45^{\prime} \mathrm{S}, 42^{\circ} 54^{\prime} \mathrm{W}\right.$, at $650 \mathrm{~m}$ altitude), in the state of Minas Gerais, Brazil. The experimental units consisted of $5 \mathrm{dm}^{3}$ plastic pots, without holes in the bottom, filled with $3 \mathrm{dm}^{3}$ of sieved (2 mm) air-dried Latossolo Vermelho-Amarelo (Santos et al., 2013), i.e., Oxisol. The original characteristics of the soil were: $5.3 \mathrm{pH}$ in water (1:2.5); $1.7 \mathrm{dag}_{\mathrm{kg}^{-1}}$ organic matter (Walkley-Black); $0.9 \mathrm{mg} \mathrm{dm}^{-3}$ available P; $7.0 \mathrm{mg} \mathrm{dm}^{-3}$ available K (Mehlich-1); 0.65, 0.02, 0.70 , and $4.10 \mathrm{cmol}_{\mathrm{c}} \mathrm{dm}^{-3}$ exchangeable $\mathrm{Ca}, \mathrm{Mg}, \mathrm{Al}$, and $\mathrm{H}+\mathrm{Al}\left(0.5 \mathrm{~mol} \mathrm{~L}^{-1}\right.$ calcium acetate extractor), respectively; $13.1 \mathrm{mg} \mathrm{L}^{-1}$ remaining $\mathrm{P}$ (Mehlich-1 extractor); and 5.2, 87.4, and $1.02 \mathrm{mg} \mathrm{dm}^{-3}$ of $\mathrm{Mn}, \mathrm{Fe}$, and $\mathrm{Zn}$ (Mehlich-1), respectively. The $\mathrm{Zn}$ availability in the soil is considered intermediate (Ribeiro et al., 1999).

Based on the soil analysis, acidity was corrected by $\mathrm{Al}$ neutralization (Ribeiro et al., 1999). $\mathrm{CaCO}_{3}$ and $\mathrm{MgCO}_{3}$ were mixed with soil to a 4:1 ratio. Then, distilled water was added to the soil, and shaken in a plastic bag until the soil reached the moisture at field capacity. The soil was then incubated for 20 days. After that, $100 \mathrm{~mL}$ of macro- and micronutrient solution were mixed with the soil. This solution contained the following nutrients (in mg kg-1 of soil): $100 \mathrm{~N}, 300 \mathrm{P}$, $150 \mathrm{~K}, 40 \mathrm{~S}, 0.81 \mathrm{~B}, 1.33 \mathrm{Cu}, 1.55 \mathrm{Fe}, 3.66 \mathrm{Mn}, 0.15 \mathrm{Mo}$, and 4.00 Zn (Novais et al., 1991). For Zn, however, the amount recommended by Novais et al. (1991) was reduced from 4.00 to $1.50 \mathrm{mg} \mathrm{kg}^{-1}$ of soil because of the addition of $\mathrm{Zn}$ that would be applied to foliage, and the intermediate $\mathrm{Zn}$ available in the soil. In the

Pesq. agropec. bras., Brasília, v.54, e01003, 2019

DOI: 10.1590/S1678-3921.pab2019.v54.01003 
second experiment, the $\mathrm{Zn}$ source of this solution was eliminated.

Five seed were sown per pot and, after emergence, the seedlings were thinned to two plants per pot. At 30 days after planting, a solution of ammonium nitrate was applied to the soil at $64 \mathrm{~kg} \mathrm{ha}^{-1}$ of $\mathrm{N}$. This application was repeated at 45 days after planting. The soil was watered daily with distilled water to keep it moist, but not soaked.

The first experiment, from February to May 2014, lasted 137 days. The temperature inside the greenhouse ranged from 15 to $38^{\circ} \mathrm{C}$. The treatments were arranged in a $(2 \times 5 \times 3)+2$ factorial design, with: the common bean cultivar BRSMG Madrepérola or Carioca 1030; $\mathrm{ZnF}$ rates at 120, 240, 480, 720, or $1200 \mathrm{~g} \mathrm{ha}^{-1}$; split applications to plants at the growth stages R5, R7, and $\mathrm{R} 8$, or R7 and R8, or at R8 only, plus zero rate for each cultivar. Both cultivars belong to "carioca" type and have indeterminate type III growth habit. The R5 growth stage corresponds to the pre-flowering, R7 to the pod formation, and R8 to the pod filling. The split $\mathrm{Zn}$ rates were divided into equal sub-rates. Treatments were replicated four times, in a randomized complete block design.

The $\mathrm{Zn}$ source was $\mathrm{ZnSO}_{4} .7 \mathrm{H}_{2} \mathrm{O}$; the $\mathrm{Zn}$ solution was applied to the foliage using a hand-held sprayer with flat fan nozzle. Before the application, the amount of water required to wet the two plants was estimated for each pot with minimum run off. Thus, the solution volume increased as plant growth progressed: $20 \mathrm{~mL}$ at $\mathrm{R} 5,40 \mathrm{~mL}$ at $\mathrm{R} 7$, and $50 \mathrm{~mL}$ at $\mathrm{R} 8$.

Gain production per pot and $\mathrm{ZnCG}$ were evaluated. Grain production was estimated with grains at $12 \%$ moisture content (wet basis). For the $\mathrm{ZnCG}$ analysis, 15 grains of each replicate were dried in an air-circulation oven at $65^{\circ} \mathrm{C}$ until a constant mass was achieved and, then, milled in a Wiley mill with a 20-mesh sieving screen. Milled grains were weighted $(0.5 \mathrm{~g})$ and digested using a nitro-perchloric solution. Grain-Zn concentrations were determined by inductively coupled plasma optical emission spectroscopy (ICP-OES) (Malavolta et al., 1997).

Based on the results of the first experiment, the second one was planned. The second experiment lasted 126 days, from August to November 2014. Temperature in the greenhouse ranged from 13 to $40^{\circ} \mathrm{C}$. Treatments were arranged in a $3 \times 6$ factorial design, which were rates of $\mathrm{Zn}$ at 0,5 , or $10 \mathrm{~kg} \mathrm{ha}^{-1}$ applied to the soil; and
$\mathrm{ZnF}$ at $0,1,1.5,3,6$ or $10 \mathrm{~kg} \mathrm{ha}^{-1}$. $\mathrm{ZnF}$ rates were much higher than in the first experiment, when their effect on $\mathrm{ZnCG}$ was linear. As the $\mathrm{ZnCG}$ of the two cultivars used in the first experiment was similar, we used for this experiment the most recently released cultivar BRSMG Madrepérola. Treatments were replicated four times, in a randomized complete block design.

For $\mathrm{Zn}$ applied to soil ( $\mathrm{ZnS})$, we mixed $\mathrm{ZnSO}_{4}$ with the total soil volume of each pot on the planting day, according to Poblaciones \& Rengel (2016). For ZnF, $20 \mathrm{~mL}$ of $\mathrm{ZnSO}_{4}$ solution was enough to wet the two plants, at the $\mathrm{R} 8$ growth stage, of each pot with minimum run off, since plants in this experiment grew less than those of the first one. The R8 growth stage was chosen for $\mathrm{ZnF}$ application because the splitting had no effect on $\mathrm{ZnCG}$, and the maximum $\mathrm{Zn}$ uptake take place in this growth stage of common bean (Moreira et al., 2018). Grain production per plant (with $12 \%$ water) and grain concentrations of $\mathrm{P}, \mathrm{K}$, $\mathrm{Ca}, \mathrm{Mg}, \mathrm{S}, \mathrm{Fe}$, and $\mathrm{Zn}$ were determined in the second experiment. For this, grains were dried, ground, and digested using a nitro-perchloric solution (Malavolta et al., 1997). The nutrient content was determined by ICP-OES.

To localize $\mathrm{Zn}$ in the grain tissues, one grain (harvested in the second experiment) was used with each $\mathrm{Zn}$ concentration $\left(22,61\right.$, and $\left.89 \mathrm{mg} \mathrm{kg}^{-1}\right)$. The cotyledons of each grain were separated from each other using a razor blade, and the cotyledon with the embryo axis attached was glued to a glass plate. Cotyledons on the plates were examined using an energy-dispersive X-ray spectrometry (EDX) to generate images.

Factorial experiments were analyzed by three-way (first experiment) or two-way (second experiment) analysis of variation, using the statistic program SAEG 9.1. The effects of $\mathrm{Zn}$ rates were evaluated by regression analysis. In the first experiment, we used two degrees of freedom to compare the zero rate with the other $\mathrm{Zn}$ rates. In the second experiment, when $\mathrm{ZnS} \times \mathrm{ZnF}$ interaction was significant, the effects of the $\mathrm{ZnF}$ rates were tested within each $\mathrm{ZnS}$ rate.

\section{Results and Discussion}

In the first experiment, cultivar, $\mathrm{Zn}$ rate, splitting, and interactions had no significant effects on grain production per pot. The soil analysis indicated intermediate $\mathrm{Zn}$ availability in the soil (Ribeiro et 
al., 1999), which together with the $\mathrm{Zn}$ fertilization at planting $\left(3 \mathrm{~kg} \mathrm{ha}^{-1}\right)$ are the probable reasons for this lack of significant effects of $\mathrm{Zn}$ rates on grain yield.

Cultivars $(\mathrm{p}=0.67)$, splitting $(\mathrm{p}=0.55)$, and cultivar $x \mathrm{Zn}$ rate $(\mathrm{p}=0.33)$, cultivar $\mathrm{x}$ splitting $(\mathrm{p}=0.67)$, and cultivar $x Z n$ rate $x$ splitting $(p=0.17)$ interactions did not affect $\mathrm{ZnCG}$. In wheat, however, the highest $\mathrm{ZnCG}$ were obtained when $\mathrm{Zn}$ was applied two (Ajiboye et al., 2015), or four (Cakmak et al., 2010) times. However, in these cases, the $\mathrm{Zn}$ rate was not split, that is, $4 \mathrm{~kg}$ of $\mathrm{ZnSO}_{4} .7 \mathrm{H}_{2} \mathrm{O}$ were applied at each growth stage. Further studies of agronomic biofortification of common bean with $\mathrm{Zn}$ in the field are necessary to complement and validate our results in greenhouse.

The contrast zero rate vs. other $\mathrm{Zn}$ rates and the effects of $\mathrm{ZnF}$ rates were significant $(\mathrm{p}<0.001)$ on $\mathrm{ZnCG}$. On average, at zero rate, $\mathrm{ZnCG}$ was $15.3 \mathrm{mg}$ $\mathrm{kg}^{-1}$ (Figure 1). The increase of $\mathrm{ZnF}$ rates from 120 to $1,200 \mathrm{~g} \mathrm{ha}^{-1}$ led to a linear increase in $\mathrm{ZnCG}$ to up $20.7 \mathrm{mg} \mathrm{kg}^{-1}$. Comparing with the zero rate, the application of 1,200 $\mathrm{g} \mathrm{ha}^{-1}$ of $\mathrm{Zn}$ increased $\mathrm{ZnCG}$ by $35 \%$. We did not use $\mathrm{Zn}$ rates higher than $1,200 \mathrm{~g} \mathrm{ha}^{-1}$ to prevent a possible leaf scorch that would be caused by the $\mathrm{Zn}$ solution because the highest rate of $\mathrm{ZnF}$ tested for correction of $\mathrm{Zn}$ deficiency in common bean is $800 \mathrm{~g} \mathrm{ha}^{-1}$ (Teixeira et al., 2008). The highest $\mathrm{ZnCG}$ achieved in this greenhouse experiment was below the range of 53.2 to $81.2 \mathrm{mg} \mathrm{kg}^{-1}$ of $\mathrm{Zn}$ obtained by Ram et al. (2016) in field experiments in Brazil, probably indicating that $\mathrm{Zn}$ available to plants in the present

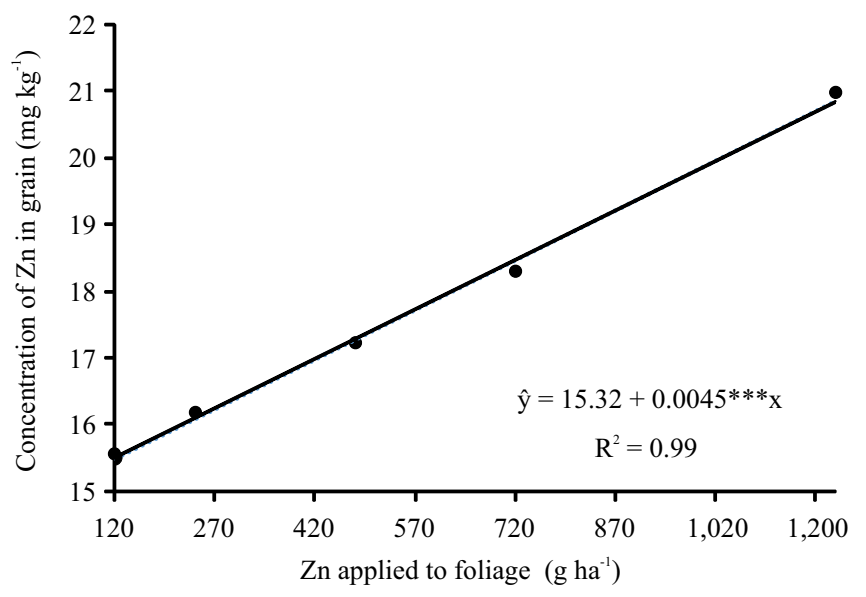

Figure 1. Effects of zinc ( $\mathrm{Zn})$ application to the foliage of common bean (Phaseolus vulgaris) on Zn concentration in grains, in a greenhouse experiment. study was low. Our results associated with those of Ram et al. (2016) suggest that $\mathrm{ZnF}$ in common bean could increase $\mathrm{ZnCG}$ by 4 to $35 \%$. In cereals, $\mathrm{ZnF}$ increases $\mathrm{ZnCG}$ more in wheat (40 to $420 \%$ ) than in rice (10 to $60 \%$ ) and maize (40\%) (Shahzad et al., 2014).

In the second experiment, $\mathrm{ZnF}(\mathrm{p}=0.30)$ and $\mathrm{ZnS} \times \mathrm{ZnF}$ interaction $(\mathrm{p}=0.90)$ did not affect grain production per pot. However, $\mathrm{ZnS}$ increased the grain production $(\mathrm{p}<0.001)$ from $2.1 \mathrm{~g}$ (without $\mathrm{Zn})$ to 13.8 $\mathrm{g}\left(5 \mathrm{~kg} \mathrm{ha}^{-1} \mathrm{Zn}\right)$ and $15.1 \mathrm{~g}\left(10 \mathrm{~kg} \mathrm{ha}^{-1} \mathrm{Zn}\right)$. Bean plants growing on soil not fertilized with $\mathrm{Zn}$ exhibited symptoms of $\mathrm{Zn}$ deficiency similar to those reported by Kabir et al. (2014).

$\mathrm{ZnS} \times \mathrm{ZnF}$ interaction had a marginal significance $(p=0.058)$ on ZnCG. Decomposition of this interaction showed that when $\mathrm{ZnS}$ was not used, the effect of $\mathrm{ZnF}$ on $\mathrm{ZnCG}$ was nonsignificant (Figure 2). It is possible that the leaf absorption of $\mathrm{ZnF}$, and $\mathrm{Zn}$ translocation into pods and deposited into grains might be impaired by biochemical and histological changes in the plants caused by Zn deficiency (Kabir et al., 2014). ZnF rates affected $\mathrm{ZnCG}$ within 5 and $10 \mathrm{~kg} \mathrm{ha}^{-1} \mathrm{ZnS}$. At $5 \mathrm{~kg}$ $\mathrm{ha}^{-1} \mathrm{ZnS}$, the maximum $\mathrm{ZnCG}\left(67.5 \mathrm{mg} \mathrm{kg}^{-1}\right)$ was achieved with $7.8 \mathrm{~kg} \mathrm{ha}^{-1}$ of $\mathrm{ZnF}$. At $10 \mathrm{~kg} \mathrm{ha}^{-1}$ of $\mathrm{ZnS}$, the maximum $\mathrm{ZnCG}\left(66.0 \mathrm{mg} \mathrm{kg}^{-1}\right)$ was obtained with $4.9 \mathrm{~kg} \mathrm{ha}^{-1} \mathrm{ZnF}$. These $\mathrm{ZnCG}$ values in common bean were higher than the targeted $56 \mathrm{mg} \mathrm{kg}^{-1}$, aimed by the HarvestPlus program (White \& Broadley, 2011). These results indicate that high rates of $\mathrm{ZnF}$ up to $10 \mathrm{~kg} \mathrm{ha}^{-1}$ $\mathrm{ZnSO}_{4} \cdot 7 \mathrm{H}_{2} \mathrm{O}$ do not cause leaf scorch in common

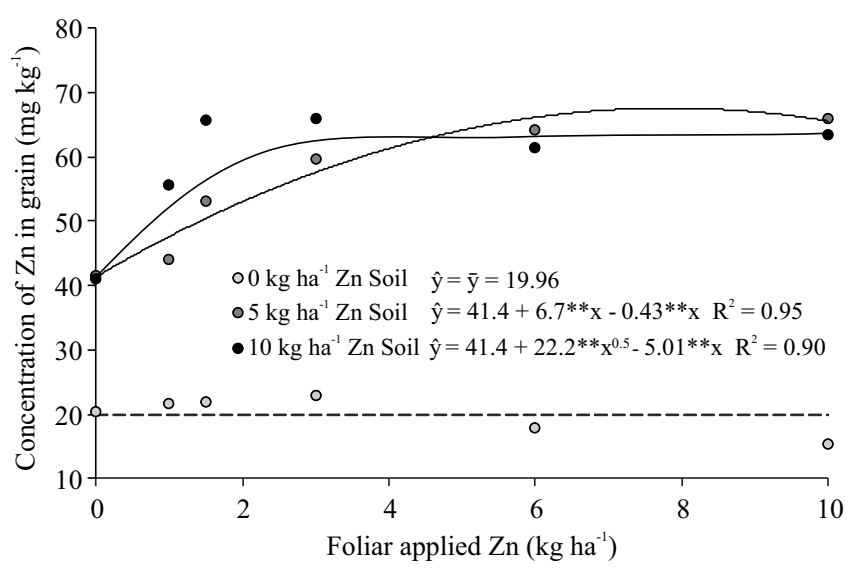

Figure 2. Interaction between rates of $\mathrm{Zn}$ applied to soil and rates of $\mathrm{Zn}$ applied to foliage of common bean (Phaseolus vulgaris) on $\mathrm{Zn}$ concentration in grain, in a greenhouse experiment. 
bean, at least in the environmental conditions where the present experiment was conducted.

Studies with rice and wheat suggest that the increase in $\mathrm{ZnCG}$ is generally much higher with $\mathrm{ZnF}$ than with ZnS (Cakmak \& Kutman, 2018). Our results differ from those obtained with cereals, since, in common bean, $\mathrm{ZnS}$ increased the $\mathrm{ZnCG}$ proportionally more than $\mathrm{ZnF}$. However, additional studies are necessary to confirm the results of the present study with common bean plants without Zn deficiency, especially under field conditions. $\mathrm{ZnF}$ has a lower effective cost than $\mathrm{ZnS}$, since $\mathrm{ZnS}$ react with soil decreasing $\mathrm{Zn}$ availability to plants (Joy et al., 2015). In addition, $\mathrm{ZnF}$ may be mixed with fungicide or insecticide (Ram et al., 2016), reducing the cost of fertilization. $\mathrm{ZnS}$ and $\mathrm{ZnF}$ combination is complementary to genetic biofortification, a long-term strategy to select genotypes with high capacity to store $\mathrm{Zn}$ in grains (Beebe et al., 2000).

$\mathrm{ZnS}$, but not $\mathrm{ZnF}$, reduced the $\mathrm{P}$ concentration in grains from 21.4 (zero $\mathrm{Zn}$ ) to $16.6\left(5 \mathrm{~kg} \mathrm{ha}^{-1} \mathrm{Zn}\right)$ and $15.8 \mathrm{~g} \mathrm{~kg}^{-1} \mathrm{P}\left(10 \mathrm{~kg} \mathrm{ha}^{-1}\right.$ of $\left.\mathrm{Zn}\right)(\mathrm{p}=0.031)$. In a $\mathrm{Zn}-$ deficient soil, a biofortification study with wheat showed that both $\mathrm{ZnF}$ and $\mathrm{ZnS}$ reduced shoot and grain $\mathrm{P}$ concentration. Phytate (responsible for the storage of $\mathrm{P}$ in plant tissues) complexes $\mathrm{Zn}$, which reduces its bioavailability. Therefore, the reduction of phytate in grains by fertilizing the plants with $\mathrm{Zn}$ means that $\mathrm{Zn}$ becomes more bioavailable in grains (Cakmak, 2008), which is desirable when the goal is to increase the bioavailability of $\mathrm{Zn}$ in food. In the present study, both forms of fertilization with $\mathrm{Zn}$ did not affect the concentration of $\mathrm{K}$ (mean $=7.81 \mathrm{~g} \mathrm{~kg}^{-1}, \mathrm{p}=0.091$ ), $\mathrm{Ca}$ $\left(\right.$ mean $\left.=1.93 \mathrm{~g} \mathrm{~kg}^{-1}, \mathrm{p}=0.450\right), \mathrm{Mg}($ mean $=1.65 \mathrm{~g}$ $\left.\mathrm{kg}^{-1}, \mathrm{p}=0.330\right), \mathrm{S}$ (mean $\left.=5.42 \mathrm{~g} \mathrm{~kg}^{-1}, \mathrm{p}=0.169\right)$, and $\mathrm{Fe}\left(\right.$ mean $\left.=21.3 \mathrm{mg} \mathrm{kg}^{-1}, \mathrm{p}=0.163\right)$ in grains. Similar grain concentrations of $\mathrm{Ca}$ and $\mathrm{Mg}$, found in the present study were also found by Ariza-Nieto et al. (2007) in common bean; however, grain concentrations of $\mathrm{K}$ and $\mathrm{Fe}$, in the present study were lower than those found by these authors, especially for Fe.

Energy-dispersive X-ray spectroscopy (EDX analysis) of grain with three $\mathrm{ZnCG}$ indicate, by colors (Figure 3), the content of $\mathrm{Zn}$ in fractions of the grains: blue, low $\mathrm{Zn}$; green, more $\mathrm{Zn}$ than the sites marked with blue; yellow, more $\mathrm{Zn}$ than the sites marked with green; and red, high $\mathrm{Zn}$. In general, the embryo axis showed the highest $\mathrm{Zn}$ content, but high concentrations of $\mathrm{Zn}$ were also observed in parts of the cotyledon. Concentration of $\mathrm{Zn}$ in the cotyledon may range between 17 (Cvitanich et al., 2011) and $41 \mathrm{mg} \mathrm{kg}{ }^{-1}$ (Blair et al., 2013), and $\mathrm{Zn}$ concentrates in the provascular region of the cotyledon (Cvitanich et al., 2011). Since, the cotyledon represents $88-91 \%$ of the bean weight (Ariza-Nieto et al., 2007), this fraction of seed contains between 83 and $94 \%$ of the total $\mathrm{Zn}$ in the grain (Cvitanich et al., 2011). The concentration of $\mathrm{Zn}$ in the embryonic axis may range from 53 to $80 \mathrm{mg} \mathrm{kg}^{-1}$ (Cvitanich et al., 2011), but this organ represents $0.6-1.8 \%$ of the bean weight (ArizaNieto et al., 2007). Grain coat represents 7.6-9.7\% of the bean weight (Ariza-Nieto et al., 2007), and the $\mathrm{Zn}$ concentration in this grain fraction may vary from 5 (Cvitanich et al., 2011) to $54.5 \mathrm{mg} \mathrm{kg}^{-1}$ (Blair et al., 2013). In wheat, the content of $\mathrm{Zn}$ in the embryo and in the aleurone layer is much higher than in the endosperm (Cakmak et al., 2010; Cakmak \& Kutman, 2018). Unlike rice and wheat, in which the edible part is

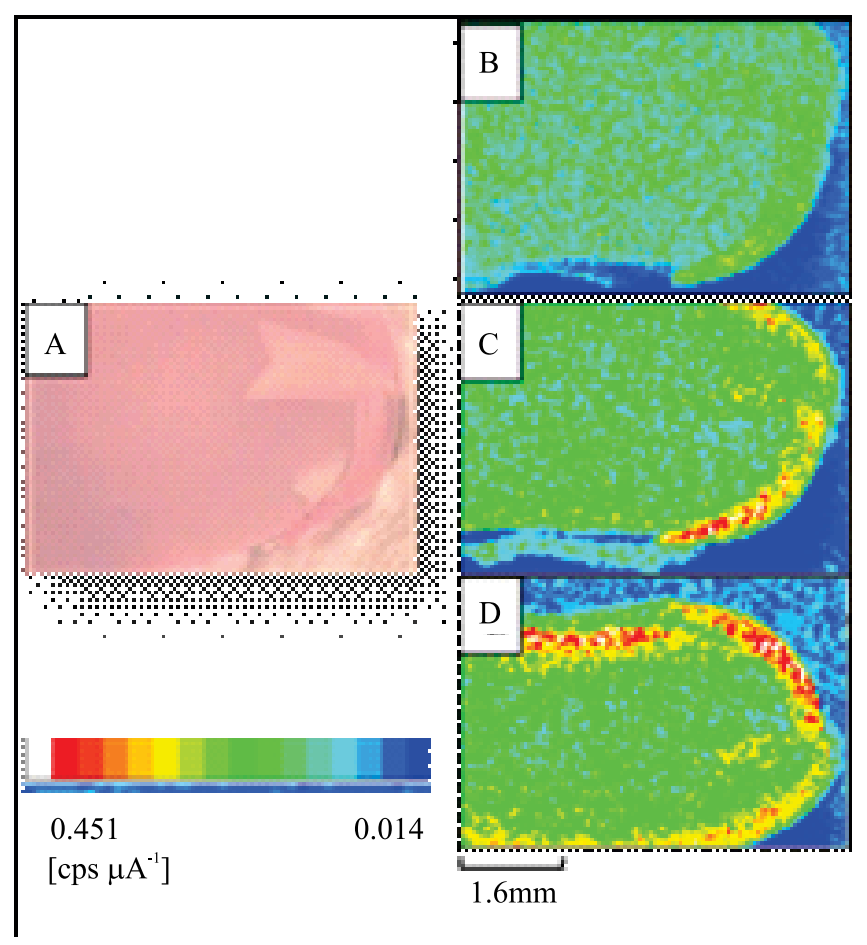

Figure 3. Grain fraction of common bean (A) used to generate energy-dispersive X-ray spectrometer images. Grain fractions were taken from samples with an average $\mathrm{Zn}$ concentration of 22 (B), 61 (C) and $87 \mathrm{mg} \mathrm{kg}^{-1}$ (D); cps, count of photons per second arriving at the detector, as $\mu \mathrm{A}^{-1}$. 
usually the endosperm, common bean does not require any processing to be edible. Compared to polished rice grains, common bean have two times more $\mathrm{Zn}$ in grains (Pfeiffer \& McClafferty, 2007). These results show the great potential of common bean to contribute to the reduction of $\mathrm{Zn}$ deficiency in countries where its consumption is high.

EDX analysis had already been validated for the selection of rice and millet genotypes with high $\mathrm{Zn}$ and Fe (Paltridge et al., 2012). Our results with common bean support this validation. In addition to be a fast and inexpensive method, EDX has these advantages: it is non-destructive; it does not use toxic chemicals; and it is performed with solid samples. EDX is a semiquantitative method and a possible lack of sample homogeneity is the main disadvantage of this method (Paltridge et al., 2012).

Determining the appropriate fertilizer management to increase the grain- $\mathrm{Zn}$ concentration is an advance in the agronomic biofortification of agricultural crops. However, quantifying the bioavailability of the accumulated $\mathrm{Zn}$ is critical, considering that $\mathrm{Zn}$ in any organ of the plant is only partially available to the human organism due to antinutritional compounds such as phytates and polyphenols. Therefore, in future studies aiming at investigate $\mathrm{Zn}$-enriched common bean grains, these antinutritional compounds should be quantified, and the bioavailability of $\mathrm{Zn}$ and $\mathrm{Fe}$ should be assessed.

\section{Conclusions}

1. The split application of $\mathrm{Zn}$ fertilizer into two or three applications on foliage, at different reproductive stages of common bean (Phaseolus vulgaris), to increase the $\mathrm{Zn}$ concentration in grains is not advantageous over a single foliar application of $\mathrm{Zn}$ at the pod filling stage.

2. The combined $\mathrm{Zn}$ application to soil and leaves increases the concentration of $\mathrm{Zn}$ in grains of common bean, in greenhouse.

\section{Acknowledgments}

To Conselho Nacional de Desenvolvimento Científico e Tecnológico (CNPq), to Coordenação de Aperfeiçoamento de Pessoal de Nível Superior (Capes), and to Fundação de Apoio à Pesquisa do Estado de Minas Gerais (Fapemig), for financial support; to José
Eustáquio de Souza Carneiro, for his support in the execution of the research; to the doctoral student Elton Eduardo Novaes Alves, for helping with the analysis in the energy-dispersive X-ray spectroscopy (EDX); and to the technicians of the department of soils and the department of plant engineering, for the support in the execution of the experiments and sample analyses.

\section{References}

AJIBOYE, B.; CAKMAK, I.; PATERSON, D.; JONGE, M.D. de; HOWARD; D.L.; STACEY, S.P.; TORUN, A.A.; AYDIN, N.; MCLAUGHLIN, M.J. X-ray fluorescence microscopy of zinc localization in wheat grains biofortified through foliar zinc applications at different growth stages under field conditions. Plant and Soil, v.392, p.357-370, 2015. DOI: https://doi. org/10.1007/s11104-015-2467-8.

ARIZA-NIETO, M.; BLAIR, M.W.; WELCH, R.M.; GLAHN, R.P. Screening of iron bioavailability patterns in eight bean (Phaseolus vulgaris L.) genotypes using the Caco-2 cell in vitro model. Journal of Agricultural and Food Chemistry, v.55, p.7950-7956, 2007. DOI: https://doi.org/10.1021/jf070023y.

BEEBE, S.; GONZALEZ, A.V.; RENGIFO, J. Research on trace minerals in the common bean. Food and Nutrition Bulletin, v.21, p.387-391, 2000. DOI: https://doi. org/10.1177/156482650002100408.

BLAIR, M.W. Mineral biofortification strategies for food staples: the example of common bean. Journal of Agricultural and Food Chemistry, v.61, p.8287-8294, 2013. DOI: https://doi.org/10.1021/ jf400774y.

BLAIR, M.W.; IZQUIERDO, P.; ASTUDILlO, C.; GRUSAK, M.A. A legume biofortification quandary: variability and genetic control of seed coat micronutrient accumulation in common beans. Frontiers in Plant Science, v.4, art.275, 2013. DOI: https:// doi.org/10.3389/fpls.2013.00275.

BOONCHUAY, P.; CAKMAK, I.; RERKASEM, B.; PROM-UTHAI, C. Effect of different foliar zinc application at different growth stages on seed zinc concentration and its impact on seedling vigor in rice. Soil Science and Plant Nutrition, v.59, p.180-188, 2013. DOI: https://doi.org/10.1080/00380768.2013.763 382.

CAKMAK, I. Enrichment of cereal grains with zinc: agronomic or genetic biofortification? Plant and Soil, v.302, p.1-17, 2008. DOI: https://doi.org/10.1007/s11104-007-9466-3.

CAKMAK, I.; KALAYCI, M.; KAYA, Y.; TORUN, A.A.; AYDIN, N.; WANG, Y.; ARISOY, Z.; ERDEM, H.; YAZICI, A.; GOKMEN, O.; OZTURK, L.; HORST, W.J. Biofortification and localization of zinc in wheat grain. Journal of Agricultural and Food Chemistry, v.58, p.9092-9102, 2010. DOI: https://doi. org/10.1021/jf101197h.

CAKMAK, I.; KUTMAN, U.B. Agronomic biofortification of cereals with zinc: a review. European Journal of Soil Science, v.69, p.172-180, 2018. DOI: https://doi.org/10.1111/ejss.12437. 
CLEMENS, S. Zn and Fe biofortification: the right chemical environment for human bioavailability. Plant Science, v.225, p.52-57, 2014. DOI: https://doi.org/10.1016/j.plantsci.2014.05.014.

CVITANICH, C.; PRZYBYLOWICZ, W.J.; MESJASZPRZYBYLOWICH, J.; BLAIR, M.W.; ASTUDILLO, C.; ORLOWSKA, E.; JURKIEWICZ, A.M.; JENSEN, E.O.; STOUGAARD, J. Micro-PIXE investigation of bean seeds to assist micronutrient biofortification. Nuclear Instruments and Methods in Physics Research B, v.269, p.2297-2302, 2011. DOI: https://doi.org/10.1016/j.nimb.2011.02.047.

JOY, E.J.M.; STEIN, A.J.; YOUNG, S.D.; ANDER, E.L.; WATTS, M.J.; BROADLEY, M.R. Zinc-enriched fertilisers as a potential public health intervention in Africa. Plant Soil, v.389, p.1-24, 2015. DOI: https://doi.org/10.1007/s11104-015-2430-8.

KABIR, A.H.; SWARAZ, A.M.; STANGOULLS, J. Zincdeficiency resistance and biofortification in plants. Jornal of Plant Nutrition and Soil Science, v.177, p.311-319, 2014. DOI: https://doi.org/10.1002/jpln.201300326.

MALAVOLTA, E.; VITTI, G.C.; OLIVEIRA, S.A. de. Avaliação do estado nutricional das plantas: princípios e aplicações. 2.ed. Piracicaba: Associação Brasileira para Pesquisa da Potassa e do Fosfato, 1997. 319p.

MOREIRA, A.; MORAES, L.A.C.; REIS, A.R. dos. The molecular genetics of zinc uptake and utilization efficiency in crop plants. In: HOSSAIN, M.A.; KAMIYA, T.; BURRITT, D.J.; TRAN, L.-S.P.; FUJIWARA, T. (Ed.). Plant micronutrient use efficiency: molecular and genomic perspectives in crop plants. London: Academic Press, 2018. p.87-108.

NOVAIS, R.F. de; NEVES, J.C.L.; BARROS, N.F. de. Ensaio em ambiente controlado. In: OLIVEIRA, A.J. de; GARRIDO, W.E.; ARAÚJO, J.D. de; LOURENÇO, S. (Coord.). Métodos de pesquisa em fertilidade do solo. Brasília: EMBRAPA-SEA, 1991. p.189-253. (Embrapa-SEA. Documentos, 3).

PALTRIDGE, N.G.; MILHAM, P.J.; ORTIZ-MONASTERIO, J.I.; VELU, G.; YASMIN, Z.; PALMER, L.J.; GUILD, G.E.; STANGOULIS, J.C.R. Energy-dispersive X-ray fluorescence spectrometry as a tool for zinc, iron and selenium analysis in whole grain wheat. Plant and Soil, v.361, p.261-269, 2012. DOI: https://doi.org/10.1007/s11104-012-1423-0.
PFEIFFER, W.H.; MCCLAFFERTY, B. HarvestPlus: breeding crops for better nutrition. Crop Science, v.47, p.S88-S105, 2007. Supl.3. DOI: https://doi.org/10.2135/cropsci2007.09.0020IPBS.

POBLACIONES, M.J.; RENGEL, Z. Soil and foliar zinc biofortification in field pea (Pisum sativum L.): grain accumulation and bioavailability in raw and cooked grains. Food Chemistry, v.212, p.427-433, 2016. DOI: https://doi.org/10.1016/j. foodchem.2016.05.189.

RAM, H.; RASHID, A.; ZHANG, W.; DUARTE, A.P.; PHATTARAKUL, N.; SIMUNJI, S.; KALAYCI, M.; FREITAS, R.; RERKASEM, B.; BAL, R.S.; MAHMOOD, K.; SAVASLI, E.; LUNGU, O.; WANG, Z.H.; BARROS, V.L.N.P. de; MALIK, S.S.; ARISOY, R.Z.; GUO, J.X.; SOHU, V.S.; ZOU, C.Q.; CAKMAK, I. Biofortification of wheat, rice and common bean by applying foliar zinc fertilizer along with pesticides in seven countries. Plant and Soil, v.403, p.389-401, 2016. DOI: https://doi.org/10.1007/ s11104-016-2815-3.

RIBEIRO, A.C.; GUIMARÃES, P.T.G.; ALVAREZ V., V.H. (Ed.). Recomendações para o uso de corretivos e fertilizantes em Minas Gerais: $5^{\text {a }}$ aproximação. Viçosa: Comissão de Fertilidade do Solo do Estado de Minas Gerais, 1999. 359p.

SANTOS, H.G. dos; JACOMINE, P.K.T.; ANJOS, L.H.C. dos; OLIVEIRA, V.A. de; LUMBRERAS, J.F.; COELHO, M.R.; ALMEIDA, J.A. de; CUNHA, T.J.F.; OLIVEIRA, J.B. de. Sistema brasileiro de classificação de solos. 3.ed. rev. e ampl. Brasília: Embrapa, 2013. 353p.

SHAHZAD, Z.; ROUACHED, H.; RAKHA, A. Combating mineral malnutrition through iron and zinc biofortification of cereals. Comprehensive Reviews in Food Science and Food Safety, v.13, p.329-346, 2014. DOI: https://doi.org/10.1111/15414337.12063 .

TEIXEIRA, I.R.; BORÉM, A.; SILVA, A.G. da; KIKUTI, H. Fontes e doses de zinco no feijoeiro cultivado em diferentes épocas de semeadura. Acta Scientiarum. Agronomy, v.30, p.255-259, 2008. DOI: https://doi.org/10.4025/actasciagron.v30i2.1739.

WHITE, P.J.; BROADLEY, M.R. Physiological limits to zinc biofortification of edible crops. Frontiers in Plant Science, v.2, art.80, 2011. DOI: https://doi.org/10.3389/fpls.2011.00080. 